\title{
TRAUMATIC BRAIN INJURY AND DRIVER SAFETY: A SYSTEMATIC REVIEW
}

\author{
Stephen Tregear, Jessica Williams, \& Damilola Funmilayo \\ MANILA Consulting Group, Inc. \\ McLean, Virginia, USA \\ Email: jwilliams@manilaconsulting.net
}

\begin{abstract}
Summary: Traumatic brain injuries (TBI) can lead to impairments in cognitive, physical, and psychosocial functions, which may ultimately affect an individual's ability to drive. A systematic review was conducted to: 1) assess the impact of TBI on crash risk/driving performance; 2) determine what factors associated with TBI are predictive of increased crash risk/poor driving performance; and 3) determine if there is a likelihood of future seizure among individuals with a TBI who did not experience a seizure at the time of the injury. Results indicated that: 1) The available evidence is insufficient to determine whether crash risk is elevated for drivers with TBI compared to uninjured controls (Summary $R R=1.32 ; 95 \% C I=0.77-2.25)$. However, driving performance was significantly impaired among individuals with TBI compared to uninjured controls (Strength of Evidence: Moderate); 2) Cognitive function measured by certain neuropsychological tests may predict the outcome of driving performance measured by a road test for patients with TBI. (Strength of Evidence: Moderate); and 3) Individuals with TBI who have not experienced a seizure within the first week post-injury still have a significant likelihood of experiencing late seizure(s). Frequencies of late seizures ranged from $1 \%$ to $25 \%$ during follow-up periods ranging from 1 to 11 years (Strength of Evidence: Moderate). The highest rate of late seizures $(25 \%)$ was associated primarily with penetrating missile TBIs (Strength of Evidence: Minimally Acceptable [32\% vs. 5\%]). These findings have potential implications for regulatory agencies with responsibility for road safety.
\end{abstract}

\section{INTRODUCTION}

Driving is a complicated psychomotor performance that depends on fine coordination between the sensory and motor systems. Many health conditions exist which have the potential to impair perception, cognition (including alertness, attitude to risk, and recall) and/or motor function and, as a result, can make driving less safe. Traumatic brain injury (TBI) is an acute injury to the brain caused by an external mechanical force. According to the Centers for Disease Control and Prevention (CDC), at least 1.4 million Americans sustain a TBI each year. Since some patients with mild TBI may not go to a hospital, this is probably an underestimate of the true number of TBIs. Immediately following a TBI, individuals usually experience a diminished or altered state of consciousness. In the longer term, TBIs may lead to temporary or permanent impairments of cognitive, physical, and psychosocial functions which can have an adverse effect on driving.

The purpose of this study was to summarize the available data on the relationship between TBI and driver performance/crash risk. The objectives were to: 1) assess the impact of TBI on crash risk/driving performance; 2) determine what factors associated with TBI are predictive of increased crash risk/poor driving performance; and 3) determine if there is a likelihood of future seizure among individuals with a TBI who did not experience a seizure at the time of the injury. 


\section{METHODS}

In order to address study objectives a systematic review was conducted. Sensitive search strategies were applied to six electronic databases (EMBASE, TRIS, DARE, Medline, PubMed [PreMedline], U.S. National Guideline Clearinghouse and the Cochrane library). Hand searches of the published literature (i.e., bibliographies of identified relevant articles that were not identified by electronic searches) and "gray literature" resources (e.g., Web searches) were also performed. Formal a priori criteria for article retrieval and inclusion for our specific objectives included: 1) English language publications, 2) full-length articles, 3) enrolled $\geq 10$ subjects, 4) subjects $\geq 18$ years, 5) must include a comparison group comprised of comparable subjects without TBI, 6) present data in a manner that allows the calculation (directly or through imputation) of effect-size estimates and confidence intervals (CI). For objective 3, studies that did not separate out patients who had early seizures or early plus late seizures from patients who had first-time late seizures were excluded.

\section{RESULTS}

\section{Direct evidence for the impact of traumatic brain injury on crash risk}

Five studies (Formisano, et al., 2005; Gouvier, et al., 1989; Haselkorn, Mueller, \& Rivara, 1998; Schanke, Rike, Molmen, \& Osten, 2008; Schultheis, Matheis, Nead, \& DeLuca, 2002) attempted to directly determine crash risk among drivers with TBI through evaluation of self-reported crashes or crashes recorded in a state licensing database. Data of the individual studies on the crash rate and severity of TBI among drivers with TBI compared to those who don't have TBI are summarized in Table 1. Only one of these studies (Schanke, et al., 2008) evaluated crash risk adjusted for distance driven, which is possibly the most important potential confounding variable. We independently calculated rate ratios to allow us to combine the data from all four studies that reported the number of events.

Table 1. Results of Studies Comparing Crash Risk of Individuals with TBI and Healthy Controls

\begin{tabular}{|c|c|c|c|c|c|c|}
\hline Reference & Year & Severity of TBI & & ults & Effect Size & p-value \\
\hline $\begin{array}{l}\text { Formisano } \\
\text { et al. }\end{array}$ & 2005 & Severe & $\begin{array}{l}\text { Crash rate: } \\
\text { TBI: } 11 / 29\end{array}$ & Expected: 4.7/29 & $\begin{array}{c}\text { Rate ratio }=2.34 \\
(95 \% \text { CI: } 0.80-6.89)^{*}\end{array}$ & $0.12^{* a}$ \\
\hline $\begin{array}{l}\text { Haselkorn } \\
\text { et al. }\end{array}$ & 1998 & NR & $\begin{array}{l}\text { \# of individuals } \\
\text { TBI: } 41 / 896\end{array}$ & $\begin{array}{l}\text { th reported crash: } \\
\text { Control: } 80 / 1625\end{array}$ & $\begin{array}{l}\text { Rate ratio }=0.93 \\
\quad(0.64-1.35)^{*}\end{array}$ & $0.70^{*}$ \\
\hline $\begin{array}{l}\text { Schanke } \\
\text { et al. }\end{array}$ & 2008 & NR & $\begin{array}{l}\text { Crash rate: } \\
\text { TBI: } 15.0 / \text { mil. } \\
\text { km driven }\end{array}$ & $\begin{array}{c}\text { Expected: } 6.25 / \mathrm{mil} . \\
\text { km driven }\end{array}$ & $\begin{array}{c}\text { Rate ratio }=2.40 \\
(95 \% \text { CI: } 0.94-6.10)^{*}\end{array}$ & $0.07^{* a}$ \\
\hline $\begin{array}{l}\text { Schneider } \\
\text { and Gouvier }\end{array}$ & 2005 & $\begin{array}{c}\text { Mild }(90 \%) \\
\text { Moderate }(10 \%)\end{array}$ & $\begin{array}{l}\text { Mean \# of crash } \\
\text { TBI: } 0.60\end{array}$ & $\begin{array}{l}\text { person: } \\
\text { Control: } 0.33\end{array}$ & $\begin{array}{l}\text { Difference in means: } \\
0.27^{*}(\mathrm{CI}: \mathrm{N} / \mathrm{A})\end{array}$ & $<0.05$ \\
\hline $\begin{array}{l}\text { Schultheis } \\
\text { et al. }\end{array}$ & 2002 & NR & $\begin{array}{l}\text { \# of individuals } \\
\text { TBI: } 10 / 40\end{array}$ & $\begin{array}{l}\text { th } 1^{+} \text {reported crashes: } \\
\text { Control: } 6 / 22\end{array}$ & $\begin{array}{l}\text { Rate ratio }=0.92 \\
\quad(0.64-2.52)^{*}\end{array}$ & $0.87 *$ \\
\hline
\end{tabular}

* Calculated by ECRI Institute; NR: Not reported; OR: Odds ratio

${ }^{*}$ Schanke et al. and Formisano et al. both reported that the difference between groups was statistically significant; our own statistical analysis used more conservative assumptions that led to non-statistically significant p-values for the between-group comparisons. 
Data from four of these studies was combined to determine an overall estimate of crash risk (Figure 1). A test for heterogeneity found that there were some differences between study results $\left(\mathrm{I}^{2}=44.9 \%\right)$ but these results were considered to be below a substantial threshold. We conducted a random effects meta-analysis to determine whether crash rates were significantly elevated among patients with TBI and if so, by what margin compared to uninjured controls or the general population. Although the summary rate ratio was $1.32(95 \% \mathrm{CI}: 0.77-2.25, \mathrm{p}=0.31)$, suggesting a slight trend toward higher risk associated with TBI, the difference between groups was not statistically significant. The results of this analysis are inconclusive because this finding does not rule out the possibility of an elevated crash risk for drivers with TBI.

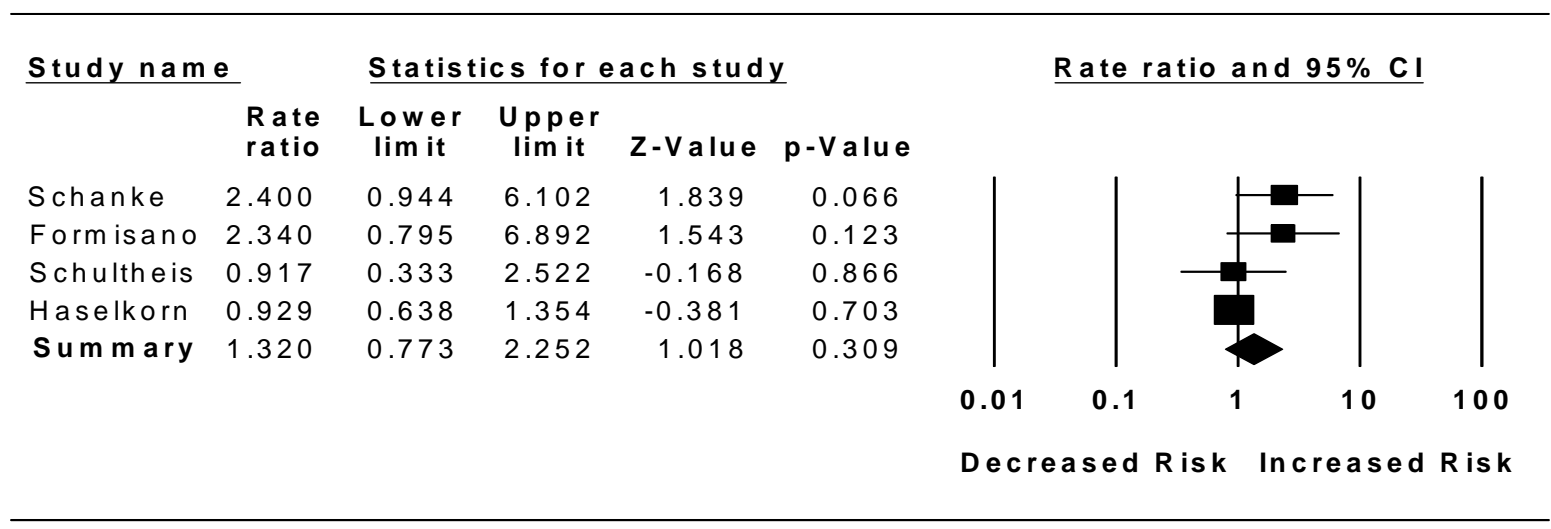

Figure 1. Meta-analysis of Crash Rate Ratios - TBI vs. Control

\section{Indirect evidence for the impact of TBI on driving performance (on-road or simulated)}

Four studies (Cyr, et al., 2009; Korteling, 1990; Lew, et al., 2005) assessed driving performance (on-road or simulated) of patients with TBI compared to healthy controls; all studies found statistically significant reduced driving performance among subjects with TBI, compared to healthy controls. None of these studies used the same measures in their assessment of driving performance, and so we reported the results of each study separately and did not attempt to combine findings in meta-analysis.

Two studies that evaluated simulated driving outcomes found statistically significant differences indicating decreased performance in at least one performance outcome for individuals with TBI compared to health controls (Cyr, et al., 2009; Lew, et al., 2005). These differences, including increases in simulated crashes and violations and fewer hits on divided attention tasks, indicated poorer performance among individuals with TBI.

Similarly, two studies that evaluated on-road driving performance found statistically significant differences in overall test scores or scores on specific driving tasks, including reaction time, delay time, and speed reproduction, that indicated decreased performance for individuals with TBI compared to healthy controls (Kewman, 1985; Korteling, 1990). Since neither study performed actual driving exams that patients would need to pass to get a driving license, the percentage of patients with TBI that would have been legally allowed to drive is unknown. Some of these individuals might never recover enough functional ability to pass a driving exam, in which case they would not be at risk for motor vehicle crash. Thus, it is possible that these 
studies may underestimate the average driving ability of the individuals with TBI who may someday be judged fit to drive.

Factors associated with traumatic brain injuries that are predictive of increased crash risk. Five studies (Coleman, et al., 2002; Formisano, et al., 2005; Pietrapiana, et al., 2005; Rapport, Bryer, \& Hanks, 2008; Schneider \& Gouvier, 2005) attempted to determine whether certain variables were associated with risk of crash/driving offenses among patients with TBI. Evidence for an association between any TBI-related factor and risk of crash/driving offenses was mixed. Two studies (with overlapping study samples) provided evidence of a significant association between neuropsychological functioning and crash/driving incidents (Coleman, et al., 2002; Rapport, et al., 2002) while two other studies did not (Pietrapina, et al., 2005; Schneider \& Gouvier, 2005) However, none of the studies used the same set of neuropsychological function tests. The conflicting evidence and low number of studies does not allow a determination of whether an association exists between any TBI-related factor and crash risk.

Factors associated with traumatic brain injuries that are predictive of poor driving performance. Seven studies (Bouillon, Mazer, \& Gelinas, 2006; Brooke, Questad, Patterson, \& Valois, 1992; Gouvier, et al., 1989; Korteling \& Kaptein, 1996; Novack, et al., 2006; Radford, Lincoln, \& Murray-Leslie, 2004; Strypstein, Arno, Eeckhout, \& Baten, 2001) evaluated the association between various predictor variables, and road-test or closed-course driving outcomes. All studies evaluated one or more neuropsychological tests as potential predictor variables. Although there was overlap in some of the tests used, none of the studies evaluated the exact same set of tests. Only the Trail-making Test (TMT) showed a significant association with road test outcome in more than one study (Brooke, et al., 1992; Novack, et al., 2006); however, a third study (Gouvier et al., 1989) did not find an association between TMT and road-test outcomes. Five studies showed significant associations between road-test outcomes and certain tests, including the Stroke Drivers Screening Assessment and Adult Memory and Information Processing Battery (Radford, et al., 2004), visual field testing and visual scanning (Strypstein, et al., 2001), perceptual speed testing and tracking reaction (Korteling \& Kaptein, 1996), the Symbol-Digit Modalities Test and the Driver Performance Test (Gouvier, et al., 1989), and the Tactual Performance Test (Brooke, et al., 1992). While it is difficult to determine which particular tests (and hence, predictor variables) have the best association with outcome, these studies suggest that poorer scores on neuropsychological tests are associated with likelihood of failure on road tests for patients with TBI.

Likelihood of a future seizure among individuals with a traumatic brain injury who did not experience a seizure at the time of injury. The percentage of individuals with a first-time late seizure ranged from $1 \%$ to $25 \%$ (Table 2) among the nine studies included for this part of our study (Annegers, et al., 1980; Annegers, Hauser, Coan, \& Rocca, 1998; Diaz-Arrastia, et al., 2003; Englander, et al., 2003; Evans, 1963; McQueen, Blackwood, Harris, Kalbag, \& Johnson, 1983; Murri, Arrigo, Bonuccelli, Rossi, \& Parenti, 1992; Weiss \& Caveness, 1972; Wohns \& Wyler, 1979). This variability is most likely due to differences in one or more factors, such as severity of TBI, how severity was determined, length of follow-up, whether children were analyzed with adults, and whether prophylactic anti-seizure medication was used in the study. Murri et al. (1992) reported the lowest percentage (1\% at 12 months) of individuals with TBI experiencing a first-time late seizure, and was the only study that reported treating all patients 
with prophylactic anti-seizure medication during an entire 12-month follow-up prior to seizure development. The study with the highest percentage of first-time late seizures $(25.2 \%)$ examined a military population (Korean War veterans), where the majority of TBIs were related to penetrating missiles (Weiss \& Caveness, 1972). Separate analysis of penetrating missile and nonmissile TBIs revealed that the rate of future seizure was 6 times higher among patients with missile injuries (31.7\%) than among patients with non-missile injuries (5.2\%; Evans, 1963). Annegers et al. (1980) found that patients with severe TBI were much more likely to experience first-time late seizures than patients with mild or moderate TBI.

Table 2. Percentage of Patients with Late Seizures Who Did Not Have an Early Seizure

\begin{tabular}{|c|c|c|c|c|c|c|c|}
\hline Reference & Year & $\begin{array}{c}\text { \# with TBI } \\
\text { (\# w/o early } \\
\text { seizure) }\end{array}$ & Severity of TBI & $\begin{array}{l}\text { Length of } \\
\text { Follow-up }\end{array}$ & \multicolumn{3}{|c|}{$\begin{array}{c}\text { Likelihood of Late Seizure Among Patients Who } \\
\text { Did Not Have an Early Seizure }\end{array}$} \\
\hline $\begin{array}{l}\text { Annegers } \\
\text { et al. }\end{array}$ & 1998 & $\begin{array}{c}4541(4424) \\
(38 \% \\
\text { children, } 62 \% \\
\text { adults })\end{array}$ & $\begin{array}{c}\text { Mild }(60.7 \%) \\
\text { Moderate }(32 \%) \\
\text { Severe }(7.2 \%)\end{array}$ & $\begin{array}{l}11 \text { years or until } \\
\text { first unprovoked } \\
\text { seizure or death }\end{array}$ & \multicolumn{3}{|c|}{$85 / 4424=1.9 \% *$} \\
\hline $\begin{array}{l}\text { Annegers } \\
\text { et al. }\end{array}$ & 1980 & $\begin{array}{c}\text { adults: } \\
1616(1587) \\
\text { children: } \\
1132(1103)\end{array}$ & $\begin{array}{l}\text { Mild }(63.6 \%) \\
\text { Moderate }(28 \%) \\
\text { Severe }(8.4 \%)\end{array}$ & NR & $\begin{array}{l}\frac{\text { TBI }}{\text { Mild: }} \\
\text { Moderate: } \\
\text { Severe: } \\
\text { Total: }\end{array}$ & $\begin{array}{c}\text { Adults } \\
8 / 1024=0.8 \% \\
5 / 441=1.1 \% \\
13 / 122=10.7 \% \\
26 / 1587=1.6 \% *\end{array}$ & $\begin{array}{c}\text { Adults }+ \text { Children } \\
12 / 1634=0.7 \% \\
14 / 893=1.6 \% \\
16 / 163=9.8 \% \\
42 / 2690=1.6 \% *\end{array}$ \\
\hline $\begin{array}{l}\text { Diaz-Arrastia } \\
\quad \text { et al. }\end{array}$ & 2003 & $106(99)$ & $\begin{array}{l}\text { Moderate or } \\
\text { severe }\end{array}$ & 6 months & \multicolumn{3}{|c|}{$17 / 99=17.2 \% *$} \\
\hline $\begin{array}{l}\text { Englander } \\
\text { et al. }\end{array}$ & 2003 & $647(626)$ & $\begin{array}{l}\text { Moderate or } \\
\text { severe }\end{array}$ & $\begin{array}{c}2 \text { years or until } \\
\text { first confirmed } \\
\text { seizure }>7 \text { days } \\
\text { after TBI }\end{array}$ & Cumulativ & $\begin{array}{r}61 / 626 \\
\text { ve probability (Kap }\end{array}$ & n-Meier) $=13.1 \%$ \\
\hline $\begin{array}{l}\text { Heikkinen } \\
\quad \text { et al. }\end{array}$ & 1990 & $55(45)$ & $\begin{array}{l}\text { Mild, moderate } \\
\quad \text { or severe }\end{array}$ & $\begin{array}{l}\text { Mean: } 5.7 \text { years } \\
\text { (range } 4.5-6.8)\end{array}$ & \multicolumn{3}{|c|}{$5 / 45=11.1 \% *$} \\
\hline Jennett & 1975 & $\begin{array}{c}\text { adults: } \\
783(663) \\
\text { total: } \\
1106(868)\end{array}$ & $\begin{array}{l}\text { Mild, moderate } \\
\quad \text { or severe }\end{array}$ & NR & $\underline{\text { Adult }}$ & $=3.3 \%$ & $\frac{\text { lts }+ \text { Children }}{868=3.3 \%}$ \\
\hline $\begin{array}{l}\text { McQueen } \\
\text { et al. }\end{array}$ & 1983 & $\begin{array}{l}164 \text { (includes } \\
43 \text { children) }\end{array}$ & Severe & 2 years & \multicolumn{3}{|c|}{$15 / 155=9.7 \% *$} \\
\hline Murri et al. & 1992 & $\begin{array}{c}293(287) \\
(30 \% \text { children } \\
70 \% \text { adults })\end{array}$ & Severe & 12 months & (all patien & $\begin{array}{r}3 / 287=1.0 \\
\text { tts had prophylaxis }\end{array}$ & $\begin{array}{l}* \\
\text { ith phenobarbital) }\end{array}$ \\
\hline $\begin{array}{l}\text { Weiss and } \\
\text { Caveness, } \\
\text { Evans }\end{array}$ & 1972 & $356(330)$ & $\begin{array}{c}\mathrm{NR} ; \\
\text { all war injuries, } \\
56 \% \text { missile, } \\
44 \% \text { nonmissile }\end{array}$ & $8-11$ years & \multicolumn{3}{|c|}{$83 / 330=25.2 \% *$} \\
\hline $\begin{array}{l}\text { Weiss and } \\
\text { Caveness, } \\
\text { Evans }\end{array}$ & 1963 & $370(343)$ & $\begin{array}{c}\mathrm{NR}, \\
59.7 \% \text { missile, } \\
40.3 \% \text { nonmissile }\end{array}$ & $2-10$ years & \multicolumn{3}{|c|}{$\begin{array}{c}\text { Missile TBI: } 66 / 208=31.7 \% * \\
\text { Nonmissile TBI: } 7 / 135=5.2 \% *\end{array}$} \\
\hline $\begin{array}{l}\text { Wohns and } \\
\text { Wyler }\end{array}$ & 1979 & $\begin{array}{c}62 \\
\text { (only } 50 \text { with } \\
\text { useful data) }\end{array}$ & Severe & Up to 2 years & \multicolumn{3}{|c|}{$\begin{array}{l}5 / 50=10 \% \\
\text { (all treated with phenytoin) }\end{array}$} \\
\hline
\end{tabular}

*Calculated by ECRI Institute; NR: Not reported 


\section{DISCUSSION}

The available evidence is insufficient to determine whether crash risk is elevated for drivers with TBI compared to uninjured controls. However, driving performance as measured by on-road driving tests and driving simulators was significantly impaired among individuals with TBI compared to uninjured controls (Strength of Evidence: Moderate). The available evidence is also insufficient to determine whether any factors related to TBI can predict actual crash risk. However, current evidence suggests that cognitive function measured by certain neuropsychological tests may predict the outcome of driving performance measured by a road test for patients with TBI (Strength of Evidence: Moderate). Evidence also suggests that individuals who have not experienced a seizure within the first week post-injury have a significant likelihood of experiencing late seizure(s). Percentages ranged from $1 \%$ to $25 \%$. Additionally, patients with penetrating missile related TBI was reported to have a much higher rate $(37.1 \%)$ compared to non-missile related TBI (5.2\%). These findings have important implications for regulatory agencies with responsibility for road safety; particularly agencies that regulate safety sensitive industries.

\section{ACKNOWLEDGEMENTS}

This research was performed under United States Department of Transportation contract number GS-10F-0177N/DTMC75-06-F-00039. The opinions of the authors expressed herein do not necessarily state or reflect those of the United States Government.

\section{REFERENCES}

Annegers, J. F., Grabow, J. D., Groover, R. V., Laws, E. R., Jr., Elveback, L. R., \& Kurland, L. T. (1980). Seizures after head trauma: a population study. Neurology, 30(7 Pt 1), 683-689.

Annegers, J. F., Hauser, W. A., Coan, S. P., \& Rocca, W. A. (1998). A population-based study of seizures after traumatic brain injuries. $N$ Engl J Med, 338(1), 20-24.

Bouillon, L., Mazer, B., \& Gelinas, I. (2006). Validity of the Cognitive Behavioral Driver's Inventory in predicting driving outcome. Am J Occup Ther, 60(4), 420-427.

Brooke, M. M., Questad, K. A., Patterson, D. R., \& Valois, T. A. (1992). Driving evaluation after traumatic brain injury. Am J Phys Med Rehabil, 71(3), 177-182.

Coleman, R. D., Rapport, L. J., Ergh, T. C., Hanks, R. A., Ricker, J. H., \& Millis, S. R. (2002). Predictors of driving outcome after traumatic brain injury. Arch Phys Med Rehabil, 83(10), 1415-1422.

Cyr, A. A., Stinchcombe, A., Gagnon, S., Marshall, S., Hing, M. M., \& Finestone, H. (2009). Driving difficulties of brain-injured drivers in reaction to high-crash-risk simulated road events: a question of impaired divided attention? J Clin Exp Neuropsychol, 31(4), 472-482.

Diaz-Arrastia, R., Gong, Y., Fair, S., Scott, K. D., Garcia, M. C., Carlile, M. C., et al. (2003). Increased risk of late posttraumatic seizures associated with inheritance of APOE epsilon4 allele. Arch Neurol, 60(6), 818-822. 
Englander, J., Bushnik, T., Duong, T. T., Cifu, D. X., Zafonte, R., Wright, J., et al. (2003). Analyzing risk factors for late posttraumatic seizures: a prospective, multicenter investigation. Arch Phys Med Rehabil, 84(3), 365-373.

Evans, J. H. (1963). The significance of early posttraumatic epilepsy. Neurology 13(207-12).

Formisano, R., Bivona, U., Brunelli, S., Giustini, M., Longo, E., \& Taggi, F. (2005). A preliminary investigation of road traffic accident rate after severe brain injury. Brain Inj, 19(3), 159-163.

Gouvier, W. D., Maxfield, M. W., Schweitzer, J. R., Horton, C. R., Shipp, M., Neilson, K., et al. (1989). Psychometric prediction of driving performance among the disabled. Arch Phys Med Rehabil, 70(10), 745-750.

Haselkorn, J. K., Mueller, B. A., \& Rivara, F. A. (1998). Characteristics of drivers and driving record after traumatic and nontraumatic brain injury. Arch Phys Med Rehabil, 79(7), 738742.

Kewman, D. G., Seigerman, C., Kintner, H. (1985). Simulation training of psychomotor skills: Teaching the brain-injured to drive. Rehabilitation Psychology 30(1), 11-27.

Korteling, J. E. (1990). Perception-response speed and driving capabilities of brain-damaged and older drivers. Hum Factors, 32(1), 95-108.

Korteling, J. E., \& Kaptein, N. A. (1996). Neuropsychological driving fitness tests for braindamaged subjects. Arch Phys Med Rehabil, 77(2), 138-146.

Lew, H. L., Poole, J. H., Lee, E. H., Jaffe, D. L., Huang, H. C., \& Brodd, E. (2005). Predictive validity of driving-simulator assessments following traumatic brain injury: a preliminary study. Brain Inj, 19(3), 177-188.

McQueen, J. K., Blackwood, D. H., Harris, P., Kalbag, R. M., \& Johnson, A. L. (1983). Low risk of late post-traumatic seizures following severe head injury: implications for clinical trials of prophylaxis. J Neurol Neurosurg Psychiatry, 46(10), 899-904.

Murri, L., Arrigo, A., Bonuccelli, U., Rossi, G., \& Parenti, G. (1992). Phenobarbital in the prophylaxis of late posttraumatic seizures. Ital J Neurol Sci, 13(9), 755-760.

Novack, T. A., Banos, J. H., Alderson, A. L., Schneider, J. J., Weed, W., Blankenship, J., et al. (2006). UFOV performance and driving ability following traumatic brain injury. Brain Inj, 20(5), 455-461.

Pietrapiana, P., Tamietto, M., Torrini, G., Mezzanato, T., Rago, R., \& Perino, C. (2005). Role of premorbid factors in predicting safe return to driving after severe TBI. Brain Inj, 19(3), 197211.

Radford, K. A., Lincoln, N. B., \& Murray-Leslie, C. (2004). Validation of the stroke drivers screening assessment for people with traumatic brain injury. Brain Inj, 18(8), 775-786.

Rapport, L. J., Bryer, R. C., \& Hanks, R. A. (2008). Driving and community integration after traumatic brain injury. Arch Phys Med Rehabil, 89(5), 922-930.

Schanke, A. K., Rike, P. O., Molmen, A., \& Osten, P. E. (2008). Driving behaviour after brain injury: a follow-up of accident rate and driving patterns 6-9 years post-injury. J Rehabil Med, 40(9), 733-736.

Schneider, J. J., \& Gouvier, W.D. (2005). Utility of the UFOV test with mild traumatic brain injury. Appl neuropsychol, 12(3), 138-142. 
Schultheis, M. T., Matheis, R. J., Nead, R., \& DeLuca, J. (2002). Driving behaviors following brain injury: self-report and motor vehicle records. J Head Trauma Rehabil, 17(1), 38-47.

Strypstein, E., Arno, P., Eeckhout, G., \& Baten, G. (2001). Ability to drive after traumatic brain injury: Neuropsychological aspects. Eura Medicophys

Weiss, G. H., \& Caveness, W. F. (1972). Prognostic factors in the persistence of posttraumatic epilepsy. J Neurosurg, 37(2), 164-169.

Wohns, R. N., \& Wyler, A. R. (1979). Prophylactic phenytoin in severe head injuries. $J$ Neurosurg, 51(4), 507-509. 